\title{
The Analysis of Self Efficacies of English Language Teachers in Terms of Creative Drama Use in Education**
}

\author{
Ata Pesen ${ }^{1}$, Burhan Üzüm ${ }^{2, *}$ \\ ${ }^{1}$ Department of Educational Sciences, Faculty of Education, Siirt University, Turkey \\ ${ }^{2}$ Department of Educational Sciences, Institute of Social Sciences, Siirt University, Turkey
}

Copyright $\bigcirc 2017$ by authors, all rights reserved. Authors agree that this article remains permanently open access under the terms of the Creative Commons Attribution License 4.0 International License

\begin{abstract}
This study was conducted to determine self-efficacy levels of English Language teachers in terms of creative drama usage. Thereby the self-efficacy of the language teachers in terms of drama usage was analyzed according to such variables as type of the school they are working, gender, length of service and any course or lesson taken about creative drama. The participants were 156 teachers working within the borders of Siirt Province, a Southeastern town in Turkey in 2015-2016 educational years and taking part in the study voluntarily. A Scale created by Can \& Canturk-Gunhan [11] called "Self Efficacy Scale in terms of Creative Drama Usage" was used to collect data. The Cronbach Alpha Reliability level was found to be 0,96 . The data collected in the study was analyzed according to independent samples t-Test, one way analysis of variance (ANOVA test), and Mann-Whitney U test in SPSS program. The results of the study show that there did not appear a meaningful difference of self-efficacy levels in terms of creative drama usage according to gender, school type or any course or lesson taken for drama usage but there was a meaningful difference as for the length of teaching years.
\end{abstract}

Keywords Creative Drama, Self-efficacy, English

\section{Introduction}

The term "Creative Drama" is being used with several literal meanings in Turkey however as it consists of different dimensions such as course, objectives, methodology, tools and aesthetic issues, the most common use of the term appears as " Creative Drama in Education." On the other hand, the term has got several different names in the literature like drama in education, creative drama or only drama as it is regarded to be different from the drama in theatre [2]. In our study, creative drama in education or creative drama only is focused on as a component of drama itself.

In general terms, drama can be explained as the imaginative power of a child [28] and a new environment [33] created by himself/herself at his/her disposal. The child perceives this environment as his/her playground. For this reason, s(he) allocates most of his/her attention and energy to the task $s(h e)$ is performing just as $s(h e)$ does while playing[29]. Humans generally have a tendency to learn, see, read in their self-created environments and feel the excitement of sharing with others. (12). In the drama in which the child is actively involved while playing, the most important issue is that the child needs to be absorbed in what $\mathrm{s}(\mathrm{he})$ is doing, search for details by his/her own methods and get to the result in the end [20].

Learning environments in which students can express themselves easily and associates the things they learn with daily life promote permanent learning. One of the methods, contributing to the thinking, interpreting and perceiving skills of students according to Biyik (2001) as cited by Maden [25], is using drama. In fact drama activates different mental processes of students.

Ashton-Hay [8] stated that drama is an efficient and useful way and technique of creating a steady and constructive learning. The author added that drama not only contributes to objective based, cooperative and self-controlled learning but also enhances the learner's emotional intelligence. In the article "Drama-Communicative Approach in English Learning as a Second Language" by Sam (32), the author highlighted that drama usage as a methodology in classroom tasks caused meaningful learning in the acquisition environment. Davies (14) in his study "Drama in English Language Learning" stated that drama has got an essential component to provide learners to reflect their individual characteristic traits and to enhance fluency and communicative skills.

Creative drama, a subcomponent of drama, can be defined as an individual's characterizing an event or experience in a group task by adding something from his/her own life experiences and making it meaningful (1). Creative drama is 
something in which an individual interprets and characterizes an experience, an incident, an idea, sometimes an abstract term or behaviour within a group task in a playful manner by making use of theatrical or drama techniques like improvisation or acting while reorganizing previous cognitive patterns and reevaluating the observations, experiences, emotions and lives [34]-[35].

Creative Drama according to Heathcote (1984) is learning itself, enlarging life experiences without stepping on the stage and acting in a play. Creative drama is playing roles of real life without knowing what life will bring in the future and getting to know what life is by this acting. [21].

For this reason, the participation of the individual, cooperation and sharing are of vital importance in creative drama. [1]-[4]. For a learner to participate in learning process actively, $\mathrm{s}(\mathrm{he})$ needs to activate his/her emotions, imagination, imaging efficacy, imaging thoughts and even his/her dreams. Creative Drama tasks enable these values to be transferred into the learning processes (35). Within Creative Drama (39) supporting correct reaction skills at the correct times, in correct places, lack of a written script, being natural and reflection of the participants' experiences and their imagined incidents under the supervision of a leader are very important components. According to Adiguzel (2) a leader/trainer or teacher who designs the process, organizes and leads is the one who is specialized in creative drama processes, has enough self-efficacy level to use creative drama in his/her own branch. Bandura (10) defines self-efficacy as the self-image and belief of oneself to succeed in the activities he plans, organizes. Bandura says that the individuals with high levels of self-efficacy beliefs tend to put great effort in what they are doing, do not step back when they face any obstacles or problems and be very patient in such situations (10).

When the literature in this issue is analyzed deeply, it appears firstly that creative drama is regarded as an art form in curriculums and an activity contributing to the learner's character development and secondly using it as a methodology in various disciplines such as history, language, math (11). From past until now, the main framework of language learning process has consisted of mainly vocabulary knowledge and main structural patterns. In such an approach, only the cognitive side of language learning is regarded as the main component. However language learning is not only a cognitive issue but also an affective phenomenon (12). Instead of classical language teaching method like Grammar-Translation method having a memorizing approach, different language skills such as reading, writing, listening and speaking have gotten more focus in language learning and teaching process (16). Creative drama in foreign language teaching creates a lot of alternatives to improve such language skills mentioned above[27]-[19]. Moreover, Creative Drama is an educational tool which reveals the imagination power and potential of an individual (26), enhances his /her social, cognitive and lingual development (17), strengthens the connection between thoughts in language and expression [14]-[45] . The achievement of such educational tools in language teaching can be possible with leaders/teachers who have creative drama self-efficacies.

There are some studies in the literature showing that language teachers tend to somehow use drama while they are teaching [9][2-5]- [43]-[31]-[15]-[23] however, there did not appear any study showing the self-efficacy capacities of Language teachers in terms of creative drama usage. The use of creative drama by the teachers is not enough on its own as it is vital for that teacher to have the necessary self-efficacy level for using creative drama in his/her lessons [30].

For this reason, this study to analyze the self-efficacy levels of language teachers in terms of creative drama use aims at contributing to the gap in the related area in the literature.

\subsection{Purpose of the Study}

The aim of the study is to analyze self-efficacy levels of language teachers in terms of creative drama use in their lessons as for improving four different language skills in foreign language teaching. Answers to the following research questions were sought for in the study;

1. At which level are English Language teachers in terms of self-efficacy in creative drama use?

2. Is there a statistically meaningful difference among the English Language teachers in terms of gender as for self-efficacy levels in creative drama use?

3. Is there a statistically meaningful difference among the English Language teachers in terms of any course or lesson taken about creative drama use as for self-efficacy levels in creative drama use?

4. Is there a statistically meaningful difference among the English Language teachers in terms of different school types as for self-efficacy levels in creative drama use?

5. Is there a statistically meaningful difference among the English Language teachers in terms of length of service as for self efficacy levels in creative drama use?

\section{Materials and Methods}

"General Survey Model", one of descriptive survey models, was used in the study. General Survey model, " in a universe consisting of too many elements, a survey conducted on a group, sample or sampling taken from that universe or the whole universe to have an evaluation of the universe." (22)

\subsection{Subjects}

The participants of the study were 296 English Language teachers working in Siirt Province, a southeastern Town in Turkey in 2015-2016 educational year from different primary, secondary and high schools. The sampling was done according to volunteer basis and therefore 156 English language teachers participated in the study in the end.

According to demographic variables the distribution of 
participants who participated in this research is shown in table 1.

Table 1. Information on the sample of the research

\begin{tabular}{|c|c|c|}
\hline & N & \% \\
\hline Gender & & \\
\hline Female & 95 & 60,9 \\
\hline Male & 61 & 39,1 \\
\hline Year of Seniority & & \\
\hline 5 years and less & 87 & 55,8 \\
\hline 6-10 years & 42 & 26,9 \\
\hline $11-15$ years & 17 & 10,9 \\
\hline 15-20 years & 6 & 3,8 \\
\hline 21 years and older & 4 & 2,6 \\
\hline Type of School & & 18,6 \\
\hline Primary School & 29 & 42,9 \\
\hline Secondary School & 67 & 38,5 \\
\hline High School & 60 & $\mathbf{1 0 0}$ \\
\hline Total & $\mathbf{1 5 6}$ & \\
\hline
\end{tabular}

Table 1 shows that 95 participants were female and 61 male out of 156.87 of those teachers had a length of service either 5 years or below, 42 of them between 6-10 years, 6 of them 11-15 years and 4 has a service of above 21 years. For this reason it may be assumed that majority of the participants in the study were mainly young teachers. 29 teachers work in primary schools, 67 of them at secondary schools and 60 in high schools. It can be said that the study was conducted on teachers having varying teaching atmospheres in different schools.

\subsection{Data Collection Tools}

During data collection period, to analyze the self-efficacy levels of the participants in terms of creative drama use, a Scale created by Can \& Canturk-Gunhan [11] called "Self Efficacy Scale in terms of Creative Drama Usage" was used according to such demographic variables as gender, length of service, type of school and whether any seminar or course taken for creative drama.

Can \& Canturk-Gunhan (11) has found the KMO value of their scale as 0,926 . The correlation matrix diagonal values of the items in the scale are between 0,826 and 0,956 . Barlett test significance value was 0,000.

Thirty six items of the 47 item scale are positive and the remaining 11 are negative ones. The items were gathered under one factor. To analyze the reliability of the scale, Cronbach Alpha was calculated and it was found to be 0,96 . ( ). In this study Cronbach Alpha level appeared as 0,90.

\subsection{Data Analysis}

The analysis of the collected data was performed by using SPSS 21.0 version of Statistical Package program. The significance level to be used in statistical analysis was $p=0,05$. To compare the means in the study, the tests namely independent samples t-Test, one way analysis of variance (ANOVA test), and Mann-Whitney $U$ test were applied. The grading criteria in the scale was subsequently; (1) I totally disagree 1:00-1.80, I disagree (2) 1,81-2.60, (3) Reasonably agree 2.61-3.40, (4) I agree 3.41-4.20 and (5) I totally agree 4.21-5.00.

\section{Findings}

The average of answers and their standard deviations as for English Language teachers self-efficacy levels for creative drama use is given in table 2 below.

Table 2 shows that English teachers with $\bar{X}=3,38$ have got self-efficacy in terms of creative drama use at "I reasonably agree level." It may be concluded from this result that the self-efficacy of English language teachers about creative drama use at a medium level.

An independent samples t-Test was applied to find whether there is a significant difference among teachers' self-efficacy in terms of creative drama use according to gender difference variable. 
Table 2. Arithmetic means and standard deviation levels as for teachers' self-efficacy levels for creative drama use

\begin{tabular}{|c|c|c|c|}
\hline & & $\bar{X}$ & Ss \\
\hline 1 & I can make the lesson entertaining by using creative drama method. & 3,55 & 1,23 \\
\hline 2 & I can enable the students to learn by doing and living by using creative drama method & 3,71 & 1,10 \\
\hline 3 & I can solve the problems of the students easily by using creative drama method. & 3,35 & 1,00 \\
\hline 4 & I can improve the students' communicative skills by using creative drama method. & 3,84 & ,991 \\
\hline 5 & I can change the students' attitudes towards the lesson in a positive way by using creative drama method. & 3,80 & 1,05 \\
\hline 6 & I can enhance the success of students by using creative drama method. & 3,74 & ,96 \\
\hline 7 & I cannot prevent students from memorizing by using creative drama method. & 2,58 & 1,10 \\
\hline 8 & I can enhance the empathy power of students by using creative drama method. & 3,78 & ,972 \\
\hline 9 & I can associate the lesson with daily life by using creative drama method. & 3,94 & 1,04 \\
\hline 10 & I can direct my student to creative thinking by using creative drama method. & 3,86 & 1,12 \\
\hline 11 & I cannot evaluate a student easily by using creative drama method. & 2,54 & 1,14 \\
\hline 12 & $\begin{array}{l}\text { I can make my students create a connection between their previous knowledge and new knowledge by using creative } \\
\text { drama method. }\end{array}$ & 3,60 & ,961 \\
\hline 13 & I enable my students to get to know themselves by using creative drama method. & 3,76 & ,873 \\
\hline 14 & I can make my students to be at peace with themselves by using creative drama method & 3,66 & ,973 \\
\hline 15 & I cannot make my students be active during the whole lesson by using creative drama method. & 2,50 & 1,24 \\
\hline 16 & I can enable my students to be brave by using creative drama method. & 3,73 & ,99 \\
\hline 17 & I can enable my student to make logical assumptions by using creative drama method. & 3,52 & 1,04 \\
\hline 18 & I can make the lessons be liked by my students by using creative drama method. & 3,57 & 1,36 \\
\hline 19 & I may not be able to enhance my students' motivation by using creative drama method. & 2,37 & 1,16 \\
\hline 20 & I can enhance my students' self-confidence by using creative drama method. & 3,65 & 1,00 \\
\hline 21 & I can associate my lessons with other related disciplines by using creative drama method. & 3,46 & 1,04 \\
\hline 22 & I can enable my students to look at the future with hope by using creative drama method. & 3,35 & 1,02 \\
\hline 23 & I cannot make my students research by using creative drama method. & 2,26 & 1,16 \\
\hline 24 & I can enable my students to be efficient in group works by using creative drama method. & 3,73 & 1,12 \\
\hline 25 & I can enhance my students' imagination power by using creative drama method. & 3,89 & 1,04 \\
\hline 26 & I can enable my students to be a challenger by using creative drama method. & 3,82 & 1,09 \\
\hline 27 & I can enable my students to reach knowledge on their own by using creative drama method. & 3,63 & ,971 \\
\hline 28 & I can enable my students to have critical minds by using creative drama method. & 3,64 & 1,09 \\
\hline 29 & I cannot create a sense of wonder in my students by using creative drama method. & 2,23 & 1,24 \\
\hline 30 & I cannot make the knowledge acquired stand forever for the students by using creative drama method. & 2,07 & 1,13 \\
\hline 31 & I can show my students different ranges of ideas by using creative drama method. & 3,66 & 1,09 \\
\hline 32 & I can use creative drama method as an educational tool in teaching. & 3,80 & 1,09 \\
\hline 33 & I can use creative drama method in an efficient way. & 3,61 & 1,06 \\
\hline 34 & I cannot improve my evaluation skills by using creative drama method. & 2,12 & 1,16 \\
\hline 35 & Creative drama enables me to start contacting with my students. & 3,78 & 1,07 \\
\hline 36 & I can solve my problems easily by using creative drama method. & 3,40 & 1,14 \\
\hline 37 & I can improve my empathy skills by using creative drama method. & 3,63 & 1,20 \\
\hline 38 & I think that I will have difficulty during the application of creative drama method. & 2,60 & 1,09 \\
\hline 39 & I can enhance my relation with other colleagues of different disciplines by using creative drama method. & 3,50 & 1,12 \\
\hline 40 & I can enhance my imagination power by using creative drama method. & 3,77 & 1,10 \\
\hline 41 & I can enhance my critical power by using creative drama method. & 3,71 & 1,17 \\
\hline 42 & I can get to know myself better by using creative drama method. & 3,80 & 1,08 \\
\hline 43 & I can improve myself to look at events from different angles by using creative drama method. & 3,82 & 1,12 \\
\hline 44 & I cannot use creative drama method in an efficient way. & 2,32 & 1,20 \\
\hline 45 & I do not know what to do when I face a problem or difficulty while I am using creative drama method. & 2,61 & 1,14 \\
\hline 46 & I can enhance my self-confidence by using creative drama method. & 3,80 & 1,06 \\
\hline 47 & I can enhance my critical thinking skills by using creative drama method. & 3,88 & 1,14 \\
\hline \multicolumn{2}{|r|}{$\mathrm{N}=156$} & 3,38 & $\mathbf{0 , 4 7}$ \\
\hline
\end{tabular}


Table 3. Independent Samples t-Test results for gender differences

\begin{tabular}{|c|c|c|c|c|c|c|}
\hline Gender & $\mathbf{n}$ & $\overline{\boldsymbol{X}}$ & $\mathbf{S S}$ & $\mathbf{d f}$ & $\mathbf{t}$ & $\mathbf{p}$ \\
\hline Female & 95 & 3,40 & 0,48 & \multirow{2}{*}{154} & 0,49 & \multirow{2}{*}{, 624} \\
\hline Male & 61 & 3,36 & 0,47 & & & \\
\hline
\end{tabular}

Table 3 indicates that there did not appear a significant difference between the female teachers about their self-efficacy levels to use creative drama $(\bar{X}=3,40)$ and male teachers $(\bar{X}=3,36)$ in which $\left(\mathrm{t}_{(154)}=0.49, \mathrm{p}>.05\right)$ value came about as shown in the table.

An independent samples t-Test was applied to find out whether there is a significant difference among teachers according to their attending or taking any course, seminar or lesson about creative drama in terms of their self-efficacy levels to use creative drama in their lessons.

Table 4. An independent samples t-Test results in terms of English Language teachers self-efficacy levels in terms of their attending or taking any course, lesson or seminar variable about the subject

\begin{tabular}{|c|c|c|c|c|c|c|}
\hline $\begin{array}{c}\text { Attending a } \\
\text { seminar }\end{array}$ & $\mathbf{n}$ & $\overline{\boldsymbol{X}}$ & SS & df & $\mathbf{t}$ & $\mathbf{p}$ \\
\hline Yes & 78 & 3,38 & 0,50 & \multirow{2}{*}{154} & $-0,57$ & \multirow{2}{*}{, 955} \\
\hline No & 78 & 3,38 & 0,45 & & & \\
\hline
\end{tabular}

There was not a significant difference between the ones who attended a course or seminar about creative drama $(\bar{X}=3,38)$ and who did not participate in similar courses $(\bar{X}=3,38)$ in terms of their self-efficacy levels to use creative drama in their lessons $\left(\mathrm{t}_{(154)}=-0,57, \mathrm{p}>.05\right)$.

One way analysis of variance (ANOVA) was performed to find out whether there was a statistically significant difference among teachers' self-efficacy levels in terms of their creative drama use according the school types they work in.

Table 5. One way analysis of variance results (ANOVA) according to school types in terms of the teachers' self-efficacy levels to use creative drama in their lessons

\begin{tabular}{|c|c|c|c|c|c|}
\hline $\begin{array}{c}\text { Type of } \\
\text { school }\end{array}$ & $\begin{array}{c}\text { Sum of } \\
\text { squares }\end{array}$ & df & $\begin{array}{c}\text { Mean of } \\
\text { squares }\end{array}$ & F & p \\
\cline { 1 - 4 } $\begin{array}{c}\text { Between } \\
\text { groups }\end{array}$ &, 204 & 2 &, 102 & \multirow{2}{*}{, 443} & 0,643 \\
\cline { 1 - 4 } $\begin{array}{c}\text { Within } \\
\text { groups }\end{array}$ & 35,28 & 153 &, 231 & & \\
\hline Total & 35,48 & 155 & & & \\
\hline
\end{tabular}

Upon looking at table 5, one may conclude that did not appear a significant difference among teachers according to the school types they are working in terms of their self-efficacy levels to use creative drama in their lessons $\left[\mathrm{F}_{(154)}\right.$ $=0,443, \mathrm{p}>.05)$ after conducting one way analysis of variance.

Kruskal Wallis test was applied to see whether there is a statistically significant difference among teachers for their self-efficacy levels to use creative drama according to their length of service in different schools.

Table 5 shows that the teachers with the least length of service years have got the most self-efficacy level while the ones having the most length of service in teaching have got the least self-efficacy level. According to Kruskal Wallis test to see whether there is a significant difference among teachers in terms of their length of service as teachers about their self-efficacy levels to use creative drama, there appeared a statistically significant difference in terms of their length of service as teachers $\left[x^{2}=17,801, \mathrm{p}<0,05\right]$. Mann-Whitney U-test to find out among which groups such a significant difference appeared, the teachers with a 1-5 year length of service outnumbered the ones with 6-10 and 20-25 years of service in terms of self-efficacy levels to use creative drama in their lessons; and also the teachers with 11-15 years of service outnumbered the ones with 21-25 years of service in terms of self-efficacy levels to use creative drama in their lessons.

Table 6. Kruskal Wallis $H$ test results according to length of service of teachers' self-efficacy levels to use creative drama in their lessons.

\begin{tabular}{|c|c|c|c|c|c|c|}
\hline $\begin{array}{c}\text { Length of } \\
\text { service }\end{array}$ & $\mathbf{N}$ & $\begin{array}{c}\text { Mean } \\
\text { rank }\end{array}$ & sd & $x^{2}$ & $\mathbf{p}$ & $\begin{array}{c}\text { Significant } \\
\text { difference }\end{array}$ \\
\hline (1) $1-5$ & 87 & 87,47 & \multirow{5}{*}{4} & \multirow{5}{*}{14,162} & \multirow{5}{*}{0,007} & \multirow{5}{*}{$\begin{array}{l}(1)-(2) \\
(1)-(5) \\
(3)-(5)\end{array}$} \\
\hline (2)6-10 & 42 & 68,04 & & & & \\
\hline (3) $11-15$ & 17 & 80,59 & & & & \\
\hline (4) $16-20$ & 6 & 55,25 & & & & \\
\hline (5)21-25 & 4 & 19,38 & & & & \\
\hline
\end{tabular}

\section{Discussion}

In this study the self-efficacy level of English teachers towards using creative drama was examined.

The mean grade the English teachers gave to scale items was 3,38. With this grade it may be assumed that the English teacher have got an "I reasonably agree" level in terms of their self-efficacy to use creative drama.

Almaz, Iseri \& Unal (6) concluded in their study that the self-efficacy perception level to use creative drama by teachers' nominees was at "I totally agree" level while in another study conducted by Sahin \& Yesilyurt (36), it was found that Turkish Language teacher nominees had a percentage as "I agree". Kilic \& Eyup (23) concluded in their study that there was a "I reasonably agree" result among teachers and for a study conducted by Cetingoz (13) on preschool teacher nominees, it appeared that their self-efficacy level was "I totally agree" level whereas Maden (25) conducted another study about self-efficacy levels of Turkish Language Teachers in which it was concluded that their self-efficacy level was " I agree" level and finally in another study conducted by Altintas \& Kaya (7) on science teachers about their self-efficacy levels to use creative drama, it appeared that their level was at "indecision" level.

Moreover Epcacan (18) and Turan, Kuguoglu \&Albayrak (40) concluded in their studies that teacher nominees felt better and self-efficient when they used creative drama activities in their lessons. There are similar findings in the literature about such result. Koc (24) found out in a study on 
teachers that teachers of class and social sciences mostly found themselves to be efficient in terms of planning, realization and evaluation skills about creative drama.

In another study conducted by Akyel (5) it was concluded that preschool teachers found themselves efficient sometimes about planning drama whereas they felt more efficient almost always when it came to realization, evaluation of drama and about the general efficacy of creative drama.

All these studies have in common is that the ones who apply creative drama has some knowledge about it to some extent but they need to have more knowledge about the subject in order to acquire best of it in their lessons (6).

In this study it was concluded that there was not a significant difference about self-efficacy levels to use creative drama in their lessons among teachers and the level of drama use method of male and female teachers was at an average level. There are similar results in various studies in the literature some of which were by Sahin \& Yesilyurt (36), Tutuman (41), Yildirim (44) and Maden (25) who conducted similar studies on teachers and found out that there was not a statistically significant difference in terms of gender about knowing the qualities of creative drama, application of it and self-efficacy levels of the teachers. On the other hand, Almaz, Iseri \& Unal (6), Turan, Kuguoglu \& Albayrak (40), Altintas \& Kaya (7) and Cetingoz 13) concluded in their studies that about the self-efficacy levels to use creative drama in their lessons, the female teachers showed a significant difference compared to male ones about their self-efficacy level in terms of gender variable.

This study showed that there did not appear a statistically significant difference among teachers in terms of their self-efficacy levels to use creative drama according to whether they attended any course or seminar about the subject.

This is while Tutuman and Demirtaş [42] reported significant difference in the knowledge and implementation level of the primary school Turkish teachers towards drama according to the seminars they had taken.

When the self-efficacy levels were compared according to the school types the teachers are working in, it was concluded that there was not any statistically significant difference among teachers about their self-efficacy levels to use drama in their lessons according to the school types like primary, secondary and high schools. Upon the search in the literature to find similar studies conducted about the relation of school types and self-efficacy levels, there appeared no study conducted specifically on this subject.

There appeared a significant difference among English Language teachers in terms of their length of service about self-efficacy levels to use creative drama in their lessons, from which it was found out that the teachers with 1-5 years of service length and the ones with 11-15 years have a more level of self-efficacy to use creative drama compared to other groups. The least self-efficient ones to use creative drama appeared those having 21 or more length of service years.
Therefore it might be concluded from this finding that the teachers with less length of service years have a tendency to be more open to use creative drama method and learner centered approaches. These findings are parallel with the ones found by Gendertou (37) having conducted a study called "Drama Teacher" in Greece and another one by Akyel (37) about Preschool educational institutions to evaluate drama efficacies of teachers. Moreover Tezer \& Aktunc (38) and Adiguzel, Akfirat \& Ozdemir (3) found out in their studies that the perceptions of teachers and the percentage of their use about creative drama showed differences according to their length of service as teachers [42].

\section{Acknowledgements}

We are very grateful to experts for their appropriate and constructive suggestions to improve this template.

\section{Note}

**The abstract of this paper was presented at 4th International Conference on Curriculum and Instruction (ICCI -EPOK. 2016), in Antalya (TURKEY) between the dates of October 27-30, 2016.

\section{REFERENCES}

[1] Adiguzel, H. O. (2006). "The Concept of Creative Drama, its components and stages" Creative Drama Journal, 1, (1).17-30.

[2] Adiguzel, H. O. (2016). Creative Drama in Education (8th Edition). Ankara: Pegem Academy.

[3] Adiguzel, H. O., Ozdemir, P. ve Akfirat, N., (2009). Nature Education vi Science and Creative. Creative Drama Journal. 4 (7) $69-76$.

[4] Aksari, S. (2005). Drama and Art Training in Preschool Educadtion by drama. Experimental Applications. Nobel Publishing.

[5] Akyel, Y. (2011). The evaluation of drama method efficacies of teachers working at preschool educational institutions. Published MA thesis. Kirsehir.

[6] Almaz, G., Iseri, K., \& Unal, E. (2014).Evaluation of Self efficacy perceptions to use creative drama of teacher nominees. International Journal of Languages ' Education and Teaching, 2(3), 48-65.

[7] Altintaş, E. \& Kaya, H. (2012). Self Efficacy and Attitudes of Science teacher nominees about performing Science and Technology lessons with Drama method. Erciyes University, Institute of Sciences Journal. 28(4), 287-295.

[8] Ashton-Hay, S. (2005) Drama: Engaging all Learning Styles. In Proceedings 9th International INGED (Turkish English 
Education Association) Conference, Economics and Technical University, Ankara Turkey.

[9] Aytas, G., \& Uysal, B. (2014). The impact of creative drama perceptions of 7th Grade students on Academic success. Language and Literature Education Journal. 2(10).

[10] Bandura A (1997) Self-efficacy: the exercise of control. New York Freeman.

[11] Can, B. \& Canturk-Gunhan, B., (2009). Self Efficacy Scale in terms of Creative Drama Use. Nwsa e-Journal Education Sciences, Volume: 4, Number: 1, p: 34-43. http://sbed.mku.edu.tr ( Published on 14th .Oct.2015)

[12] Calıskan, N. \& Karadag, E., (2014). Drama in Education: Theoretical basis and Samples of applications. Ankara: Ani Publishing.

[13] Cetingoz, D. (2012). Self Efficacy levels of Preschool Education Teacher Nominees in terms of use of Creative Drama Method. Hacettepe University, Faculty of Education Journal. Ankara: Hacettepe University Publications. 42, 131-142.

[14] Davies, P (1990). The Use of Drama in English Language Teaching TESL Canada Journal/Revue Tesl Du Canada Vol. 8, No.1, November

[15] Dellal, A. N., \& Kara, Z. (2010). The awareness level of Foreign Language Teacher Nominees and Teachers about Drama Techniques. Language Journal. 149, 7-29.

[16] Demirel, O. (1990). Principles, Methods and Techniques of Foreign Language Teaching. Ankara: Usem Publishing. 6.

[17] Dougill, J. (1987). Drama Activities for Language Training. Londra:Macmillan.

[18] Epcacan, C. (2012). The Perceptions of the students of Faculty of Education in terms of Drama Method Efficiency. Ekev Academy Journal. 16(52), 281-298.

[19] Fleming, M. (1995). Starting Drama Teaching. London: David Fulton Publisher.

[20] Gonen, M. \& Dalkilic, N. U. (1998). Drama in child Education, Epsilon Publishing, Istanbul.

[21] Hornbrook, D. (1990). Education and Drama. Oxford.

[22] Karasar, N. (1994). Scientific Research Method. Ankara: Nobel Publishing.

[23] Kiliç, S., \& Tuncel, M. (2009). The Impact of Creative Drama on English Speaking and Attitude. Abant Izzet Baysal University. Journal of Faculty of Education, 9(2).

[24] Koc, I. (2013). The identification of Efficacies of teachers using and applying drama method and techniques in Sciences lessons. Unpublished MA thesis. Kirsehir. Ahi Evran University. Institute of Social Sciences.

[25] Maden, S. (2010). Self efficacies of Turkish Language Teachers about the use of Drama Methodology. Mustafa Kemal University. Journal of Institute of Social Sciences. 7(14), 259-274.

[26] Maley, A. \& Duff, A. (1978). Drama Techniques in Language Education. Cambridge: Cambridge University Publishing.
[27] Mc Caslin, N. (1990). Creative Drama in The Classroom (Fifth Edition). New York: Longman.

[28] O’Neill, C. \& Lambert, A., (1990). Drama Structures A Practical Handbook for Teacher, Heinemann Educational Book Inc. London.

[29] Onder, A., (1999). Educational Drama for Learning by experience. Epsilon Publishing, Istanbul.

[30] Önder, A. (2003). Okulöncesi çocukları için yaratıcı drama uygulamaları. İstanbul: Morpa Kültür Yayınları

[31] Ozcelik, N., \& Aydeniz, H. (2012). Yaratıcı Drama Yönteminin Üniversite Öğrencilerinin Akademik Başarılarına ve Fransızca Konuşmaya Yönelik Tutumlarına Etkisi/Impact of Creative Drama Method on the Academic Achievement of University Students and Their Attitude towards Speaking French. Atatürk University, Journal of the Institute of Social Sciences, 16(2).

[32] Sam, W.Y (1990). Drama in Teaching English as a Second Language - A Communicative Approach. The English Teacher Vol XIX July 1990.

[33] San, I. (1996). A Discipline to improve creativeness and creative individual. Educational Drama, New Turkey Journal, 2(7), 148-160

[34] San, I. (1998). The Past and Present of Creative Drama Studies in Turkey, Proceedings of Second National Child Culture Conference. edt. B. Onur) Ankara: ATAUM Publishing.

[35] San, I. (2002). Creative Drama- Educational Dimensions, What is Educational Creative Drama? What is not? Creative Drama (1985-95 Publications, Ed. H. Omer ADIGUZEL). Ankara: Naturel Publishing.

[36] Sahin, A., \& Yesilyurt, E. (2014). Self Efficacy levels of Turkish Language Teaching Department students in terms of Drama Methodology use. Usak University, Social Sciences Journal, $7 / 3$.

[37] Gendertou, P. (2002). Drama Teacher Training in Greece: A survey of attitudes of teachers towards drama teachers, Journal of Education for Teaching, 28:2, 123-133

[38] Tezer, M., \& Aktunç, E. (2010). Teacher opinions in the implementation of the drama method in mathematics teaching. Procedia-Social and Behavioral Sciences, 2(2), 5836-5840.

[39] Toytok, E. H., \& Ac1kgoz, A. (2013). The Relationship between the conflict management styles and organizational justice perceptions of school administrators according to teachers' ideas. Journal of Anatolian Educational Leadership and Teaching, 1(2), 24-36.

[40] Turan, I., Kuguoglu, I. H. \& Albayrak, O. (2012). Self efficacy of drama for teacher nominees and Drama use in Geography, History and Citizenship Lessons. e-Journal of New World Sciences Academy. 7(3).

[41] Tutuman, O. Y. (2011). Self Efficacies of Turkish Language Teachers in terms of Creative Drama Applications. Unpublished MA Thesis. İzmir: Dokuz Eylkul University. Institute of Educational Sciences.

[42] Tutuman, O. Y., \& Demirtas, V. Y. (2013). Self Efficacies of Turkish Language Teachers in terms of Creative Drama Applications. Abant Izzet Baysal University, Journal of Faculty of Education. 
[43] Yenilmez, K., \& Uygan, C. (2010). The impact of Creative Drama Methodology on the self-efficacy perceptions of /th grade students in terms of Geometry lesson. Kastamonu Journal of Education, 18(3), 931-942.

[44] Yildirim, İ. N. (2008). The identification of efficacy and application levels of Primary School First stage teachers in terms of creative Drama use. Unpublished MA Thesis. Elazig: Firat University. Institute of Social Sciences.
[45] Zyoud, M. (2010). Using Drama Activities and Techniques to Foster Teaching English as a Foreign Language: A Theoretical Perspective. Al Quds Open University, 1-11.

http://www.qou.edu/arabic/researchProgram/researchersPage s/muntherZyoud/research_1.pdf accessed on 13/08/16. 